Naser, Pelacakan Gerakan Tangan Untuk...13

\title{
PELACAKAN GERAKAN TANGAN UNTUK PENGENALAN GERAK-ISYARAT
}

\author{
Naser Jawas \\ STMIK STIKOM Bali \\ Jalan Raya Puputan no.86 Renon Denpasar \\ e-mail: naser.jawas@stikom-bali.ac.id
}

\begin{abstract}
Abstrak
Pelacakan gerakan tangan (hand tracking) adalah metode yang digunakan untuk melacak pergerakan tangan dalam sebuah rangkaian frame video. Pelacakan gerakan tangan ini merupakan salah satu pekerjaan yang penting dalam aplikasi-aplikasi interaksi antar manusia dan komputer (human computer interaction) yang menggunakan gerak-isyarat tangan. Tidak seperti pada pelacakan anggota badan lainnya, tangan memerlukan penanganan yang berbeda karena dalam citra bentuk tangan dapat berubah akibat dari pergerakan persendian sehingga informasi / fitur bentuk tangan tidak dapat dikatakan reliable untuk proses pelacakan gerakan tangan. Hanya fitur warna dan fitur gerak yang dapat dikatakan reliable untuk pelacakan gerakan tangan. Oleh karena itu, pada penelitian ini diusulkan sebuah metode untuk melakukan pelackan gerakan tangan dengan memanfaatkan penggabungan beberapa fitur seperti gerak dan warna dengan tetap mempertahankan kesederhanaan komputasi. Kesederhanaan komputasi didapatkan dengan melakukan seleksi fitur yang akan dilacak sehingga fitur yang dilacak tidak terlalu banyak namun fitur-fitur tersebut memang merupakan fitur kunci yang dapat memberikan penanda yang baik untuk metode pelacakan gerakan. Pada penelitian ini digunakan 2 buah algoritma untuk mendeteksi gerakan tangan yakni mean shift dan optical flow. Keduanya dapat melakukan deteksi gerakan namun masih memiliki beberapa kesalahan deteksi yang menyebabkan penurunan tingkat akurasi deteksi gerakan tangan
\end{abstract}

Kata kunci: Pelacakan gerakan tangan, mean shift, optical flow.

\begin{abstract}
Hand tracking is a method to detect the movement of a hand object in a series of video frame. It is one of important methods in human computer interaction applications. Hand is different from any other body parts in the matter of detection and tracking because hand can have different form from frame to frame due to the movement in the joints part. Movements in the joints make information / feature of the hand shape not realiable for hand tracking. Therefore, in this research a method for hand tracking using integration of movement and color is used to detect hand movement while preserve the computation simplicit $y$. The computation simplicity is maintained by using feature selection. The selected feature is not too much but it is the key feature to represent the movement. In this research, 2 methods for feature generation is used. They are mean shift and optical flow. Those methods can be used for hand tracking but there are still much false detection which causing low hand tracking accuracy.
\end{abstract}

Kata kunci: hand tracking , mean shift, optical flow.

\section{Pendahuluan}

Pelacakan gerakan tangan (hand tracking) adalah metode yang digunakan untuk melacak pergerakan tangan dalam sebuah rangkaian frame video. Pelacakan gerakan tangan ini merupakan salah satu pekerjaan yang penting dalam aplikasi-aplikasi interaksi antar manusia dan komputer (human computer interaction) yang menggunakan gerak-isyarat tangan (Wu, Y. et.al., 2005). Pelacakan gerakan tangan merupakan pondasi dari pengenalan gerak-isyarat tangan karena untuk dapat mengenali gerak-isyarat tangan dibutuhkan pelacakan yang dapat melacak gerakan tangan 
dengan baik. Tidak seperti pada pelacakan anggota badan lainnya, tangan memerlukan penanganan yang berbeda karena dalam citra bentuk tangan dapat berubah akibat dari pergerakan persendian sehingga informasi / fitur bentuk tangan tidak dapat dikatakan reliable untuk proses pelacakan gerakan tangan. Hanya fitur warna dan fitur gerak yang dapat dikatakan reliable untuk pelacakan gerakan tangan (Zhang, X. et.al., 2015).

Kendala dalam mendapatkan fitur warna adalah ketika warna tangan dan warna background memiliki perbedaan yang rendah sehingga pelacakan berdasarkan fitur warna ini akan mengalami kegagalan. Selain itu, warna dalam satu titik di frame sebelum dan sesudah memiliki perbedaan karena adanya perubahan intensitas warna.

Fitur kedua adalah fitur gerak. Fitur gerak ini sangat umum digunakan dalam pelacakan gerakan. Fitur gerak yang paling umum diadopsi adalah fitur gerak optical flow (Beauchemin, S.S., et.al., 1995). Optical flow menggambarkan pergerakan 2 dimensi dari piksel-piksel dalam citra yang berurutan.

Pelacakan gerakan tangan menggunakan sebuah fitur saja dinilai kurang cukup untuk lelakukan pelacakan yang handal sehingga dibutuhkan penggabungan dari beberapa fitur untuk dapat melakukan pelacakan gerakan tangan yang baik. Banyak penelitian yang telah mencoba melakukan integrasi pelacakan gerakan dengan menggabungkan beberapa fitur (Erdem, E., et.al., 2012, Wang, Q., et.al. 2014, Zhang, X. et.al., 2015). Selain penggabungan beberapa fitur tersebut, permasalahan untuk menghemat komputasi dengan menerapkan seleksi fitur yang baik untuk dilacak juga penting (Shi, J., et.al., 1994). Namun meskipun telah banyak makalah yang membahas tentang pelacakan gerakan tangan ini, metode pelacakan gerakan tangan yang handal masih menjadi problem yang terbuka lebar untuk diteliti. Permasalahan yang sering terjadi adalah kesalahan pelacakan karena ketidak mampuan metode untuk tetap melacak dengan benar dari satu frame ke frame yang lain saat tangan bergerak melewati background yang mempersulit pendeteksian tangan. Oleh karena itu, pada penelitian ini diusulkan sebuah metode untuk melakukan pelackan gerakan tangan dengan memanfaatkan penggabungan beberapa fitur seperti gerak dan warna dengan tetap mempertahankan kesederhanaan komputasi. Kesederhanaan komputasi didapatkan dengan melakukan seleksi fitur yang akan dilacak sehingga fitur yang dilacak tidak terlalu banyak namun fitur-fitur tersebut memang merupakan fitur kunci yang dapat memberikan penanda yang baik untuk metode pelacakan gerakan.

\section{Tinjauan Pustaka}

Pada penelitian oleh Erdem et.al. tahun 2012 ini dilakukan penggabungan data fitur gerak dengan memanfaatkan particle filter. Kontribusi pada penelitian ini adalah pada proses penggabungan fitur gerak yang digunakan didasarkan pada fitur mana yang paling reliable secara dinamis. Sehingga algoritma pelacak ini dapat beradaptasi terhadap perubahan yang terjadi pada video sehingga akurasi pelacakan juga dapat ditingkatkan. Perubahan atau pemilihan fitur ini didasarkan pada pemberian bobot yang berbeda dari masing-masing fitur. Sebelum pemberian bobot, dilakukan prediksi untuk menentukan particle yang mana yang akan digunakan. Prediksi ini dilakukan dengan sebelumnya mengenerasi beberapa nilai random yang terdistribusi secara merata (Erdem, E., et.al., 2012).

Wang et.al. pada tahun 2014 menggunakan kamera RGB-D untuk mendeteksi gerakan. Kamera RGB-D adalah kamera yang tidak hanya dapat menangkap citra seperti kamera pada umumnya, namun juga dapat menentukan informasi kedalaman (depth). Ada tiga fitur yang digunakan dalam penelitian ini, yaitu optical flow, warna dan kedalaman. Optical flow digunakan untuk menunjukkan estimasi pergerakan dari target. Kemudian lokasi yang lebih tepat didapatkan dengan memanfaatkan fitur warna dan kedalaman dari kamera RGB-D. Penentuan lokasi dengan lebih detail dengan memanfaatkan fitur warna dan kedalaman ini menggunakan membagi target ke dalam beberapa bagian diantaranya adalah bagian kanan dan kiri, dan bagian atas dan bawah. Pembagian target ke dalam beberapa bagian ini dilakukan untuk mengantisipasi target yang terhalang beberapa bagiannya oleh objek lainnya di video (Wang, Q., et.al. 2014). 
Pada penelitian Zhang ini dilakukan penggabungan fitur gerak dan fitur warna yang didapatkan dari kamera digital biasa. Fitur warna yang digunakan adalah warna dalam ruang warna HSV sedangkan fitur gerak yang digunakan tersebut diwakilkan dari beberapa particel yang degenerate pada lokasi disekitar lokasi target awal. Particle tersebut kemudian diseleksi kembali untuk digunakan dalam pendeteksian gerak. Ada 3 kriteria yang digunakan pada seleksi fitur yakni diverse, representative, dan compact. Ketiga fitur tersebut digunakan pada saat seleksi particle yang akan digunakan untuk mendeteksi lokasi dan perpindahan / gerakan tangan dari frame ke frame. Gambar 1 menunjukkan bagan rancangan dari algoritma yang dibawakan oleh Zhang et.al. (Zhang, X. et.al., 2015).

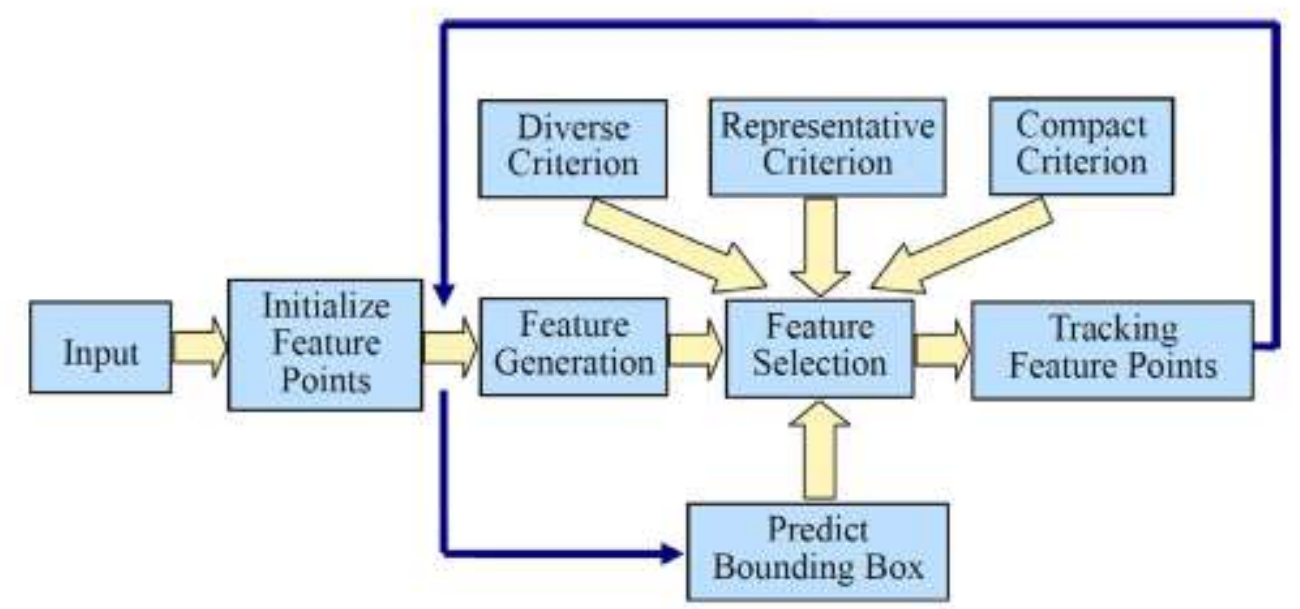

Gambar 1. Rancangan Algoritma Zhang X. et.al.

\section{Metode Penelitian}

\section{Tempat dan Waktu Penelitian}

Penelitian ini dilakukan di STMIK STIKOM Bali Jl. Raya Puputan no.86 Renon Denpasar. Penelitian ini dilakukan selama 5 bulan dari Januari hingga Mei 2016.

\section{Data}

Data yang digunakan dalam penelitian ini adalah data citra berurutan yang diekstrak dari frameframe video. Ada 2 jenis data yang digunakan yakni data yang berasal dari dataset visual object tracking (VOT) challenge dan juga data yang direkam sendiri menggunakan kamera dari telpon genggam berresolusi 5 Mega Piksel. Gambar 2 menunjukkan contoh data dari dataset VOT.

\section{Gambar 2. Contoh Dataset VOT}

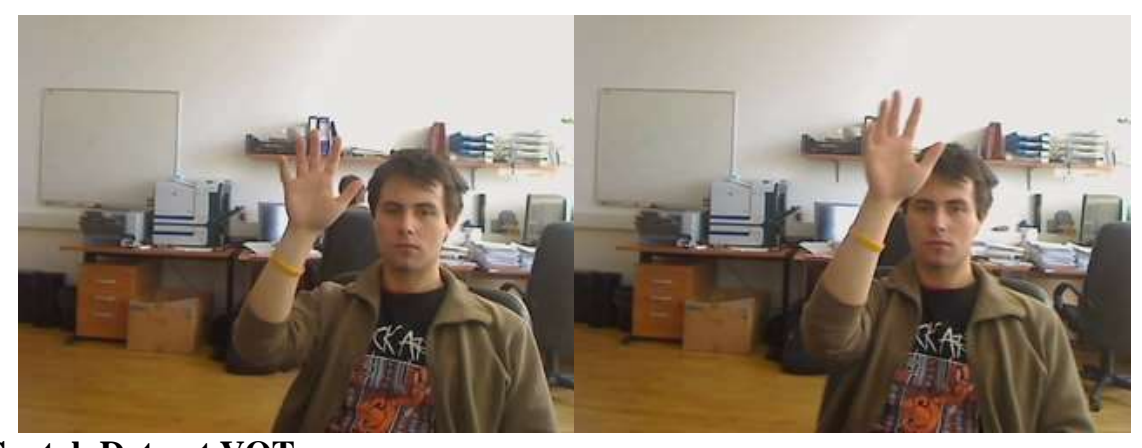

\section{Alur Penelitian}

Penelitian ini akan dilakukan dengan langkah-langkah sebagai berikut: Pertama akan dilakukan studi literature untuk mempelajari metode-metode yang terkait dengan pelacakan gerakan tangan. Literatur yang digunakan adalah makalah yang berasal dari jurnal ilmiah internasional dengan kurun waktu penelitian paling lama 5 tahun yang lalu. Namun, apabila dari sebuah makalah 
menggunakan metode yang berasal dari makalah yang lebih dari 5 tahun, maka makalah itu akan tetap dimasukkan ke dalam kajian studi literatur untuk mempermudah memahami metode yang sedang dibahas.

Langkah berikutnya adalah merumuskan dan merancang algoritma untuk melakukan pelacakan gerakan tangan berdasarkan studi literatur yang telah dilakukan. Pada perancangan algoritma ini, diharapkan dapat diberikan kontribusi keilmuan berupa sebuah pengembangan algoritma yang baru dengan harapan dapat memperbaiki proses pelacakan tangan.

Selanjutnya, algoritma yang telah dirancang tersebut, diimplementasikan ke dalam bahasa pemrograman. Pada penelitian ini digunakan bahasa pemrograman python dengan memanfaatkan library opencv untuk mempermudah implementasi algoritma.

Langkah selanjutnya adalah melakukan pengujian hasil dari algoritma yang dirancang. Pengujian dilakukan dengan menghitung nilai error dengan membandingkan dengan ground truth. Ground truth dihasilkan secara manual oleh pengamat / manusia terhadap posisi tangan pada sebuah citra. Posisi tangan yang telah ditentukan oleh pengamat tersebut dibandingkan dengan posisi tangan yang didapatkan oleh algoritma pelacakan dan dihitung berapa jarak perbedaannya. Semakin besar jaraknya maka semakin besar nilai error nya.

Berikutnya hasil penelitian dituliskan ke dalam bentuk laporan penelitian dan makalah untuk dipublikasikan ke jurnal ilmiah. Gambar 3 menunjukkan bagan dari alur penelitian ini.

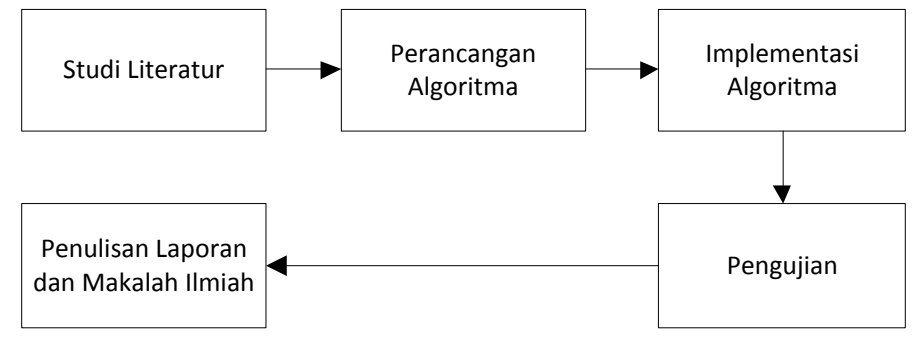

\section{Gambar 3 Alur Penelitian}

\section{Alur Algoritma}

Alur dari algoritma pelacakan gerakan tangan ini dimulai dengan sebuah input citra dengan menandai awal dari posisi tangan. Kemudian dilakukan pembacaan citra di frame selanjutnya dan dideteksi perpindahan dari posisi sebelumnya dengan mengambil beberapa kriteria penilaian. Hal ini dilakukan secara berulang-ulang hingga tiba di citra frame terakhir. Gambar 4 menunjukkan bagan alur algoritma tersebut.

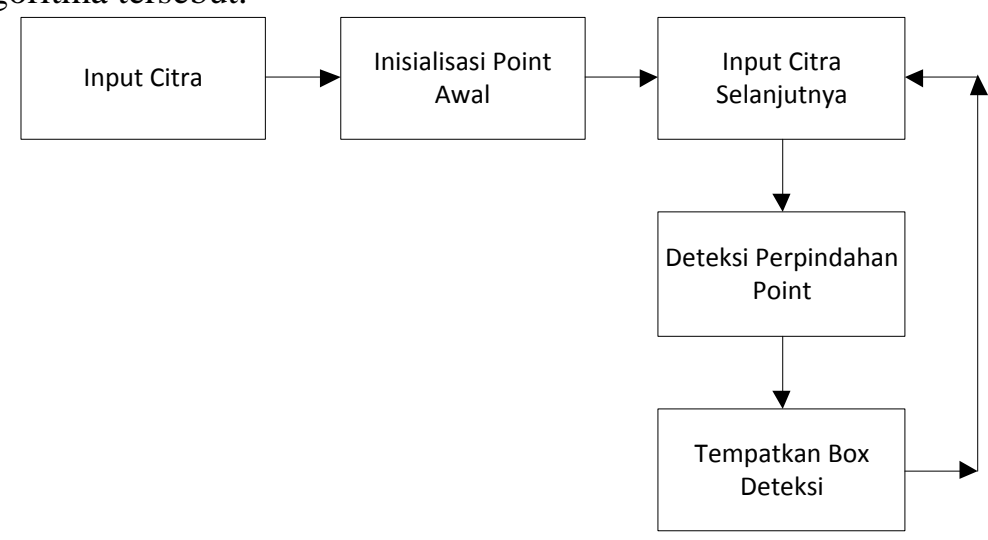

\section{Gambar 4. Alur Algoritma}

\section{Hasil dan Pembahasan}

\section{Rancangan Algoritma Pelacakan Gerakan Tangan}

Algoritma pelacakan gerakan tangan ini dirancang dengan memanfaatkan algoritma deteksi fitur dari Shi dan Tomasi. Algoritma tersebut digunakan untuk mendeteksi titik-titik yang baik untuk dilacak. Algoritma Shi dan Tomasi tersebut akan mendeteksi titik-titik sudut pada sebuah area. 
Titik-titik sudut tersebut yang dinilai baik untuk digunakan sebagai titik pelacakan. Karena hasil dari algoritma Shi dan Tomasi tersebut kurang banyak dalam mendapatkan titik-titik yang cocok untuk dideteksi, maka dilakukanlah penambahan secara random (Zhang, X. et.al., 2015). Hasil penambahan secara random tersebut harus diseleksi kembali untuk memastikan titik-titik fitur tersebut memang mewakili daerah tangan. Pada penelitian (Zhang, X. et.al., 2015) digunakan 3 fitur. Pada penelitian ini ke-3 fitur tersebut dievaluasi kembali dan apabila memungkinkan akan ditambahkan dengan beberapa fitur baru untuk meningkatkan akurasi pelacakan gerakan tangan. Gambar 5 menunjukkan bagan dari algoritma pelacakan gerakan tangan ini secara umum. Pada awal mulai pelacakan dilakukan input citra dan penentuan area tangan secara manual terlebih dahulu. Pada area tersebutlah dilakukan pendeteksian fitur dengan algoritma Shi dan Tomasi serta penambahan titik fitur secara random. Selanjutnya setelah dilakukan seleksi fitur, dilakukanlan pelacakan perubahan posisi dari titik-titik tersebut. Tentunya aka nada banyak titik yang hilang, maka pada perulangan selanjutnya di frame selanjutnya, dilakukanlan kembali deteksi fitur dan penambahan secara random. Namun kali ini dilakukan didalam batasan kotak dari titik-titik pada frame sebelumnya.

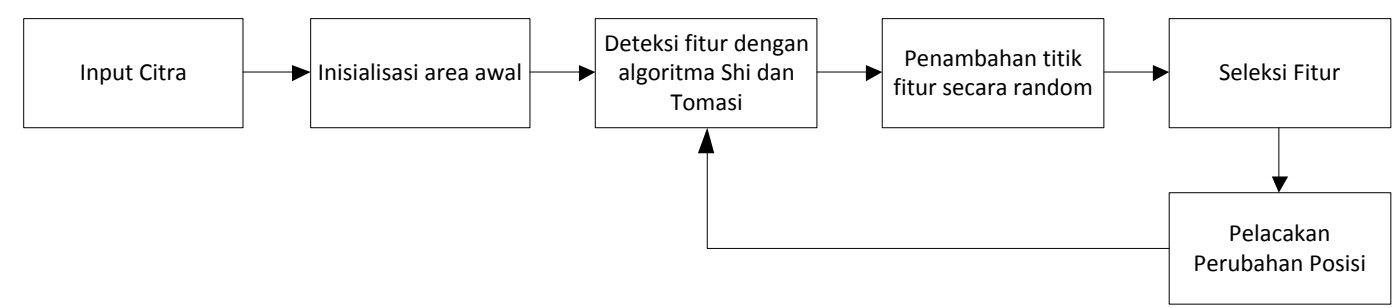

\section{Gambar 5. Algoritma Pelacakan Gerakan Tangan}

\section{Implementasi Algoritma Shi dan Tomasi}

Algoritma Shi dan Tomasi adalah algoritma untuk mementukan titik-titik sudut dalam sebuah citra. Titik-titik tersebut dinilai merupakan titik-titik yang baik digunakan untuk melakukan pelacakan. Algoritma Shi dan Tomasi ini sudah terdapat di OpenCV sehingga implementasi nya cukup mudah. Fungsi yang digunakan adalah fungsi goodFeatureToTrack. Gambar 6 menunjukkan hasil dari deteksi titik sudut dengan menggunakan algoritma Shi-Tomasi pada seluruh citra.

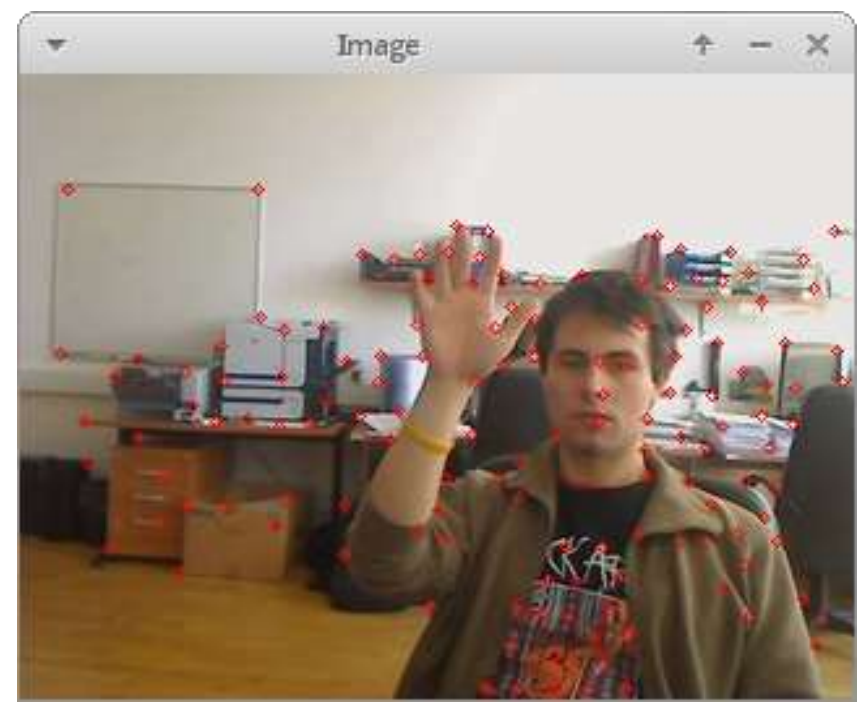

Gambar 6. Hasil Deteksi Algoritma Shi dan Tomasi

\section{Implementasi Pemilihan Region Manual}

Sesuai dengan algoritma yang dirancang, pemilihan region tangan dilakukan secara manual untuk frame pertama. Dari region di frame pertama tersebut kemudian akan dilakukan pencarian titik-titik sudut dengan algoritma Shi dan Tomasi. Gambar 7 menunjukkan hasil pemilihan manual dan 
kemudian dilanjutkan dengan deteksi titik-titik sudut di dalam region yang dipilih secara manual tersebut. Pemilihan region manual tersebut juga diimplementasi dengan menggunakan OpenCV.

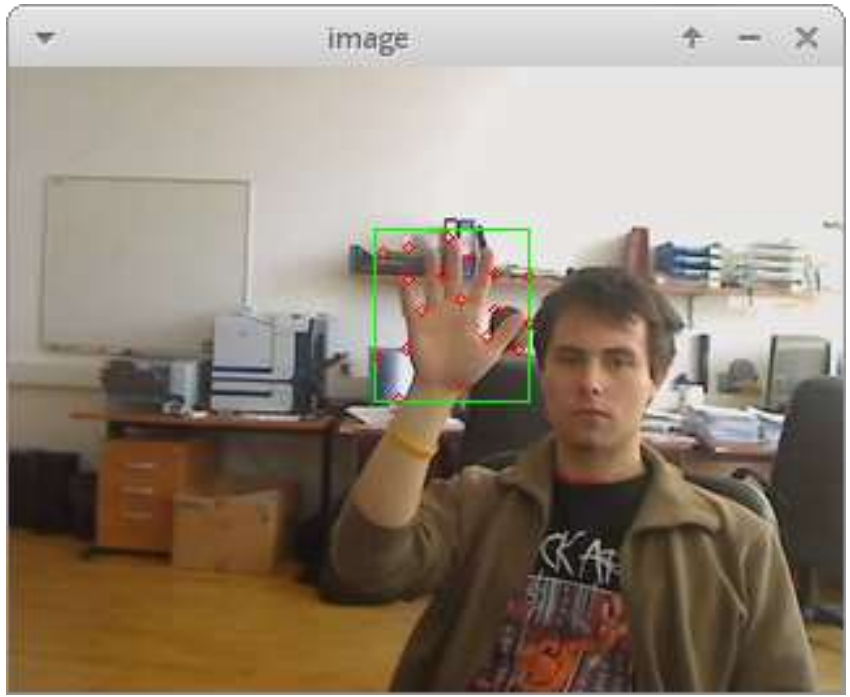

\section{Gambar 7. Pemilihan Region Manual dan Deteksi Shi-Tomasi}

\section{Implementasi Algoritma Tracking MeanShift}

Algoritma meanshift digunakan untuk melakukan tracking object berdasarkan nilai warna object tersebut. Warna yang digunakan pada algoritma ini adalah warna dalam ruang warna HSV. Sehingga perlu dilakukan perubahan ruang warna dari warna RGB ke HSV sebelum melakukan pendeteksian pergerakan. Gambar 8 menunjukkan hasil pendeteksi gerakan menggunakan algoritma Mean Shift. Pada ketiga gambar tersebut (a) hingga (c), Mean Shift berhasil menandai area lokasi yang merupakan daerah kulit tangan. Gambar (a) adalah gambar acuan awal yang ditetapkan secara manual, sedangkan Gambar (b) dan (c) mengikuti.

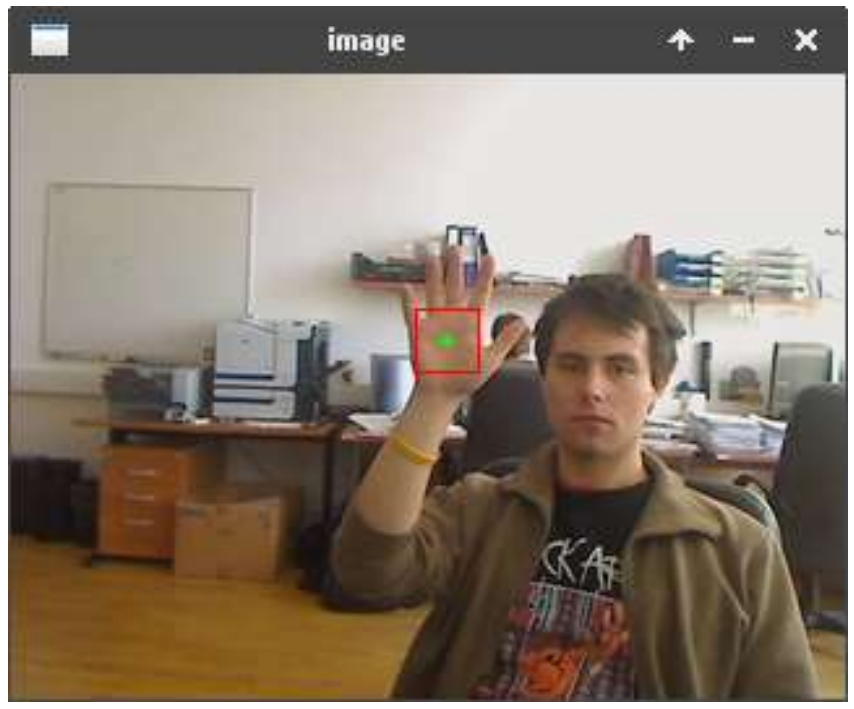

(a) 


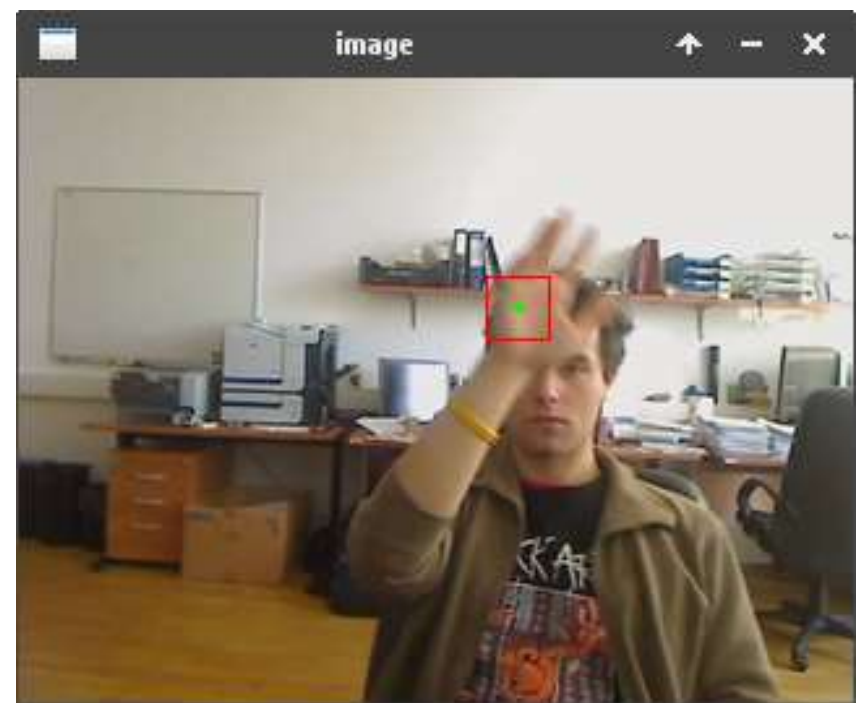

(b)

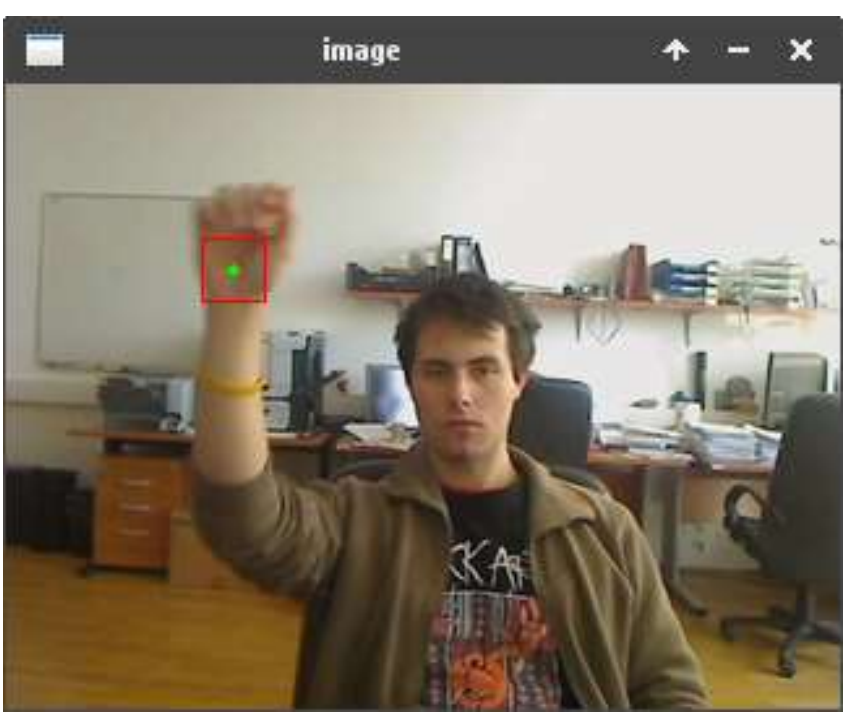

(c)

Gambar 8. Implementasi Mean Shift

\section{Implementasi Shi Tomasi dalam Area Mean Shift}

Selanjutnya dilakukan inisialisasi titik dengan algoritma Shi Tomasi di dalam area Mean Shift. Titik-titik ini yang kemudian digunakan untuk pendeteksian gerakan menggunakan algoritma deteksi optical flow. Selain mendapatkan titik-titik dengan menggunakan algoritma Shi Tomasi, titik-titik juga ditambahkan secara acak. Penambahan titik secara acak ini dilakukan apabila titiktitik hasil Shi Tomasi belum mencapai batas minimum. Gambar 9 menunjukkan hasil dari implementasi ini. 


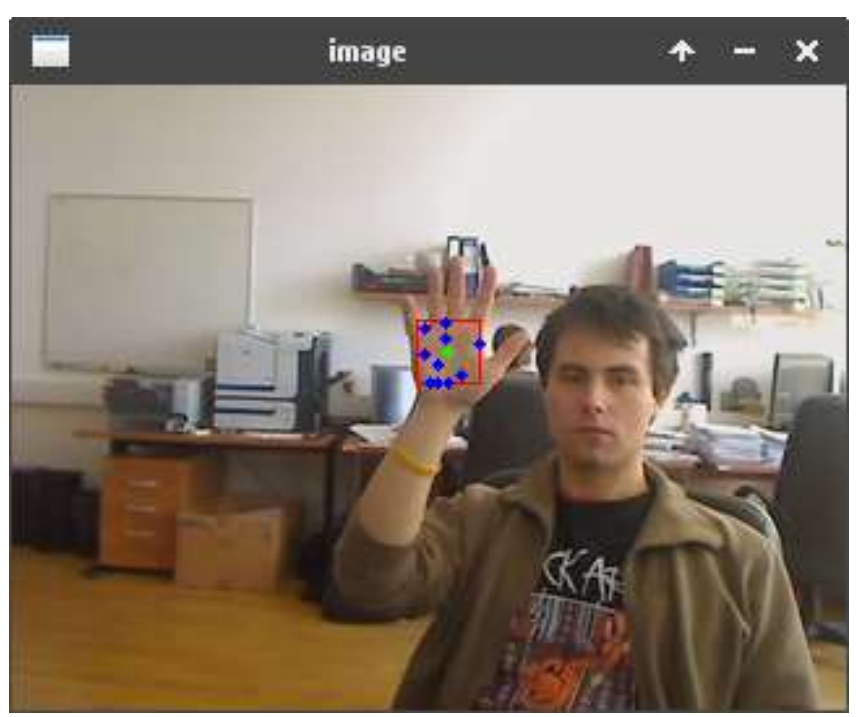

\section{Gambar 9. Genrate Titik Shi Tomasi di Area Mean Shift}

Pada. Gambar 9 Algoritma Shi Tomasi hanya mendapatkan 4 titik saja sehingga dilakukan penambahan secara acak hingga terdapat 10 titik di dalam kotak yang telah ditandai oleh mean shift.

\section{Implementasi Optical Flow}

Titik-titik yang telah didapatkan dari proses sebelumnya kemudian diinputkan ke algoritma optical flow untuk mendeteksi pergerakan dari titik tersebut berdasarkan pergerakan optical flow. Gambar 10 menunjukkan hasil dari implementasi optical flow terhadap titik-titik yang telah didapatkan dari proses sebelumnya.

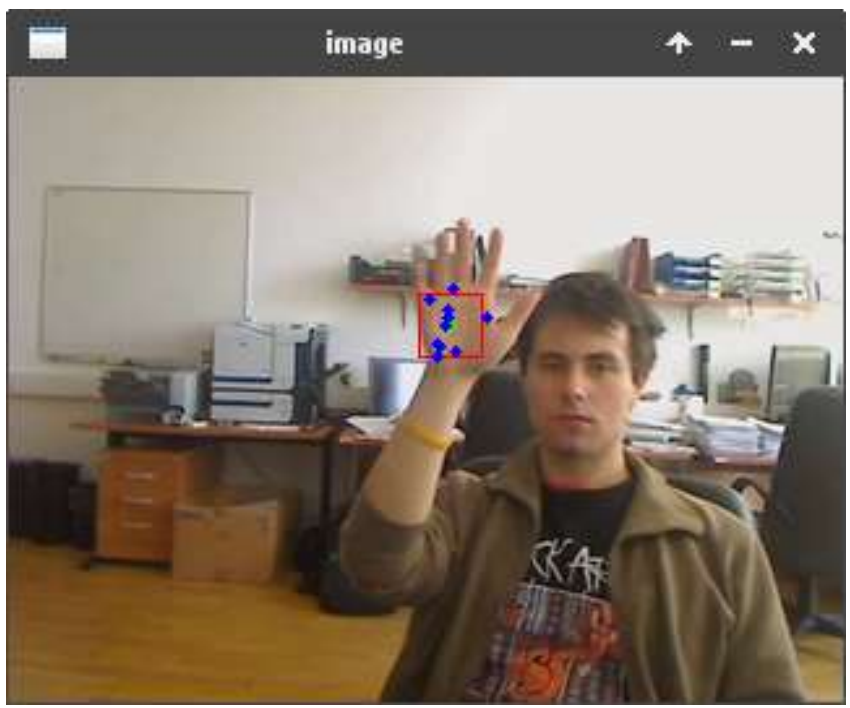

(a) 


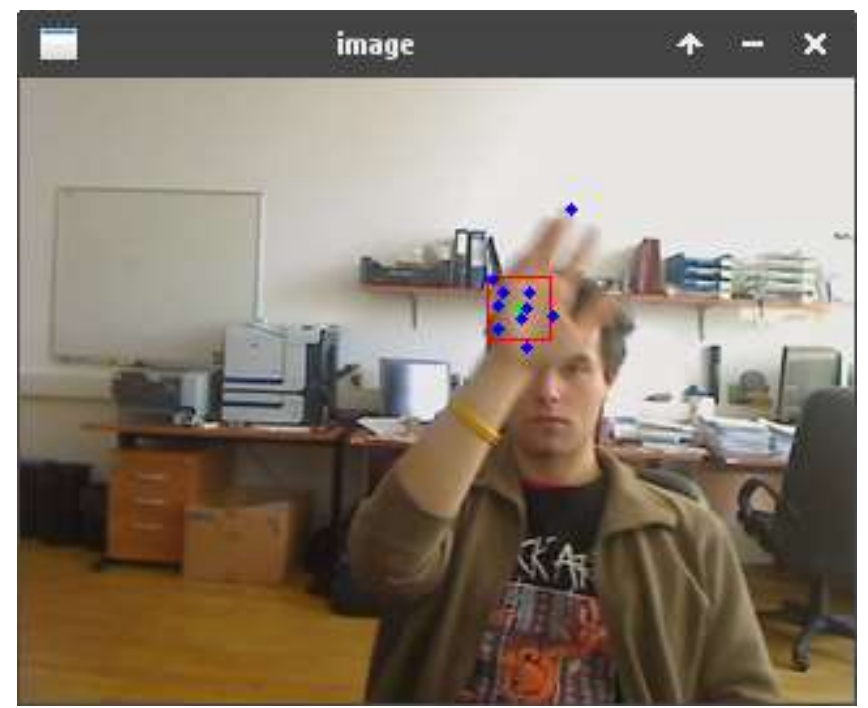

(b)

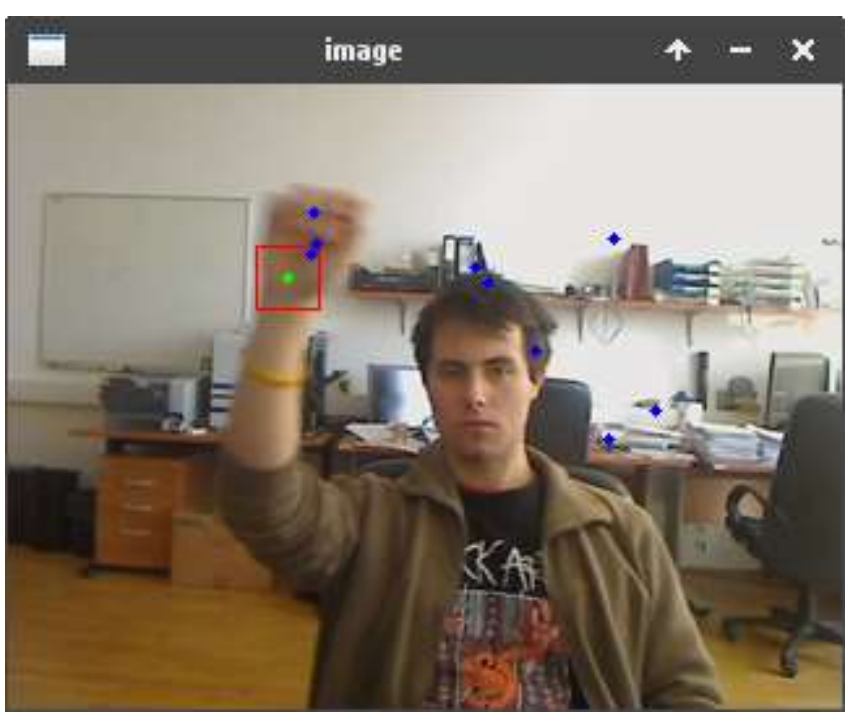

(c)

\section{Gambar 10. Implementasi Optical Flow}

Gambar 10 (a) masih menunjukkan hasil yang baik dimana optical flow masih memiliki gerakan yang sama dengan mean shift. Namun pada Gambar 10 (b) dan Gambar 10 (c) sudah terlihat perubahan yang jauh antara gerak mean shift dengan gerak optical flow dari titik-titik yang disiapkan.

\section{Pembahasan}

Dari gambar-gambar yang ditampilkan, terlihat kelemahan yang ada dari implementasi 2 buah metode pelacakan gerak ini untuk digunakan bersama-sama. Sehingga diperlukan sebuah algoritma untuk dapat membuat keduanya bekerja sama saling memperbaiki pendeteksian gerakan tangan agar hasil deteksi gerakan lebih akurat. Mean Shift masih memiliki kelemahan dimana apabila tangan melewati daerah yang memiliki warna yang serupa dengan warna tangan maka area deteksi mean shift akan dapat bergeser dari tangan ke area tersebut. Apalagi diiringi dengan perubahan warna di daerah tangan. Gambar 11 (a) tangan bergerak ke arah bawah yang mendekati dengan warna tangan dan pada Gambar 11 (b) kotak mean shift tidak lagi mengikuti gerakan tangan karena mendeteksi warna yang mirip pada area yang salah. 


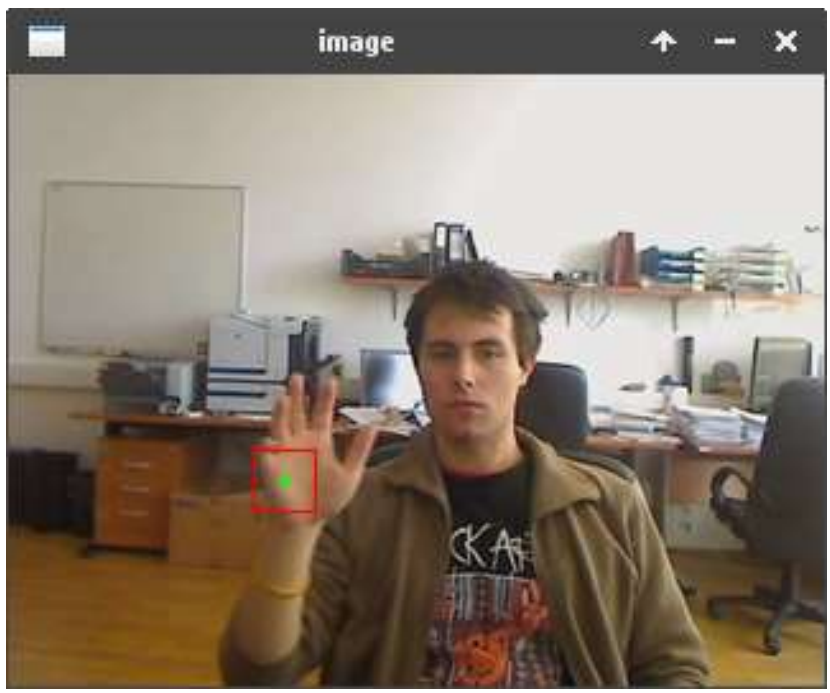

(a)

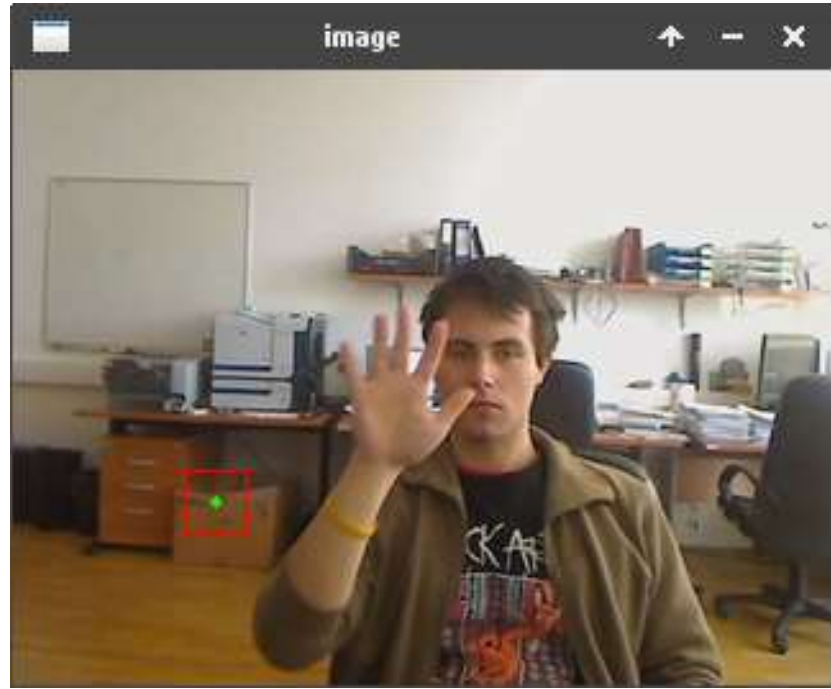

(b)

\section{Gambar 11. Kesalahan Mean Shift}

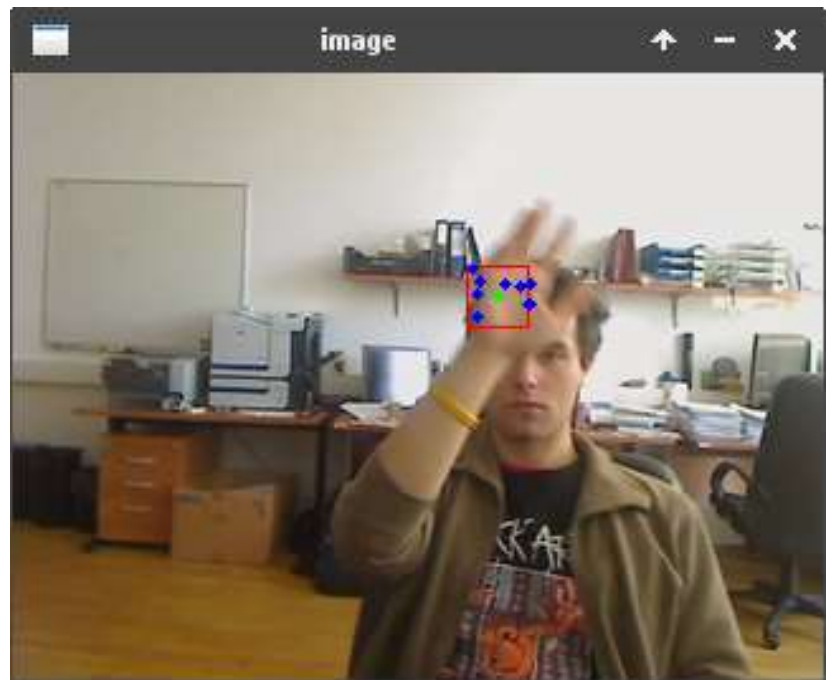

(a) 


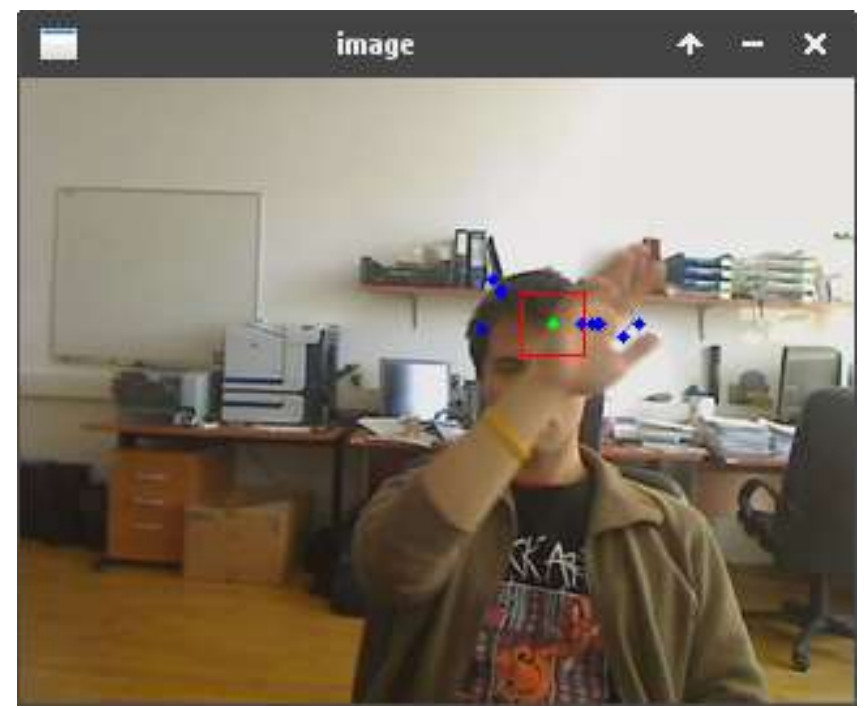

(b)

\section{Gambar 12. Kesalahan Optical Flow}

Pada optical flow juga mengalami kesalahan yang mirip dengan mean shift dalam mendateksi perubahan atau pergerakan. Optical Flow apabila salah dalam mendekteksi perubahan nilai piksel dan pergerakan piksel maka akan salah dalam menemukan lokasi dari titik-titik setelah perubahan seperti ditunjukkan pada Gambar 12.

\section{Simpulan}

Pada penelitian ini digunakan 2 buah algoritma untuk mendeteksi gerakan tangan yakni mean shift dan optical flow. Keduanya dapat melakukan deteksi gerakan namun masih memiliki beberapa kesalahan deteksi yang menyebabkan penurunan tingkat akurasi deteksi gerakan tangan. Pada penelitian selanjutnya sebaiknya dikembangkan algoritma untuk dapat membuat mean shift dan optical flow dapat bekerja bersama untuk saling mendukung meningkatkan akurasi deteksi gerakan tangan.

\section{Daftar Pustaka}

1 Beauchemin, S.S., and Barron, J.L. (1995). The Computation of Optical Flow. ACM Computing Surveys, vol. 27, no. 3.

2 Erdem, E., Dubuisson, S., Bloch, I. (2012). Visual Tracking by Fusing Multiple Cue with Context-Sensitive Reliabilities. Patter Recognition vol. 45.

3 Shi, J., and Tomasi, C. (1994). Good Features to Track.

4 Wang, Q., Fang, J., Yuan, Y. (2014). Multi-Cue Based Tracking. Neurocomputing vol. 131.

5 Wu, Y., Lin, J., Huang, T.S. (2005). Analyzing and Capturing Articulated Hand Motion in Image Sequences. IEEE Transactions on Pattern Analysis and Machine Intelligence, vol. 27 , no. 12 .

5 Zhang, X., Li, W., Ye, X., Maybank, S. (2015). Robust Hand Tracking Via Novel MultiCue Integration. Neurocomputing, vol. 157. 